Check for updates

The BMJ

Cite this as: BMJ 2020;370:m3087 http://dx.doi.org/10.1136/bmj.m3087 Published: 04 August 2020

\section{Covid-19: UK hospitals to get rapid tests from September}

\section{Elisabeth Mahase}

The UK government has spent $€ 161 \mathrm{~m}$ ( $€ 178 \mathrm{~m}$; \$210m) on 5.8 million covid-19 testing kits, which will be rolled out across NHS hospitals from September and can provide a result within 90 minutes.

The RNA tests will be analysed by 5000 "Nudgebox" machines, supplied by London based consumer company DnaNudge. The machines can process up to 15 nose swabs a day without the need for a laboratory.

Imperial College London-where the technology was designed-claims that the machines can also check for influenza A, influenza B, and respiratory syncytial viruses, and include a control assay for human RNA which eliminates false negative results by testing for inadequate swabbing.

Researchers reported that trials comparing the technology with several NHS laboratory results indicated 98\% sensitivity and 100\% specificity. Several machines have already been rolled out in eight London hospitals and are being used in cancer wards, emergency departments, and maternity wards.

Gary Davies, hospital medical director of Chelsea and Westminster Healthcare NHS Foundation Trust, which is using the Nudgebox tests in its emergency and elective surgery departments, told The BMJ, "The opportunity to have this highly accurate test-without the need for a laboratory-is helping us to provide the highest quality care for our patients and support for our staff, and offers the best chance of tackling the biggest challenge that the NHS has ever faced, particularly now as we look ahead to the winter flu season."

The government has also purchased 450 ooo LamPORE swab tests for adult care settings and laboratories, which will be rolled out next week. The Department of Health and Social Care said the tests can process swab and saliva samples to detect the presence of covid-19 in 60 to 90 minutes, and that they have the "same sensitivity as the widely used PCR swab test."

The corresponding desktop machine can process up to 15 ooo tests a day, while the palm sized version can process up to 2000 tests a day and can be deployed in "near community pop-up labs."

Jon Deeks, professor of biostatistics at Birmingham University, has warned, however, that these tests could "put lives at risk" as their claims have not been independently substantiated. He said, "Repeatedly throughout the pandemic the government has raced ahead purchasing tests on the basis of manufacturer's claims, and have found later when independent studies are done that the tests don't have adequate performance for use in the NHS.

"We would hope that the government would wait for proper evaluations and consider the evidence for all available tests before signing further contracts. The mistakes made in test purchasing have wasted millions of pounds as well as put lives at risk."

The announcement that more tests are being purchased for adult care settings comes after the Sunday Times reported that ministers have abandoned a key pledge to test all people in care homes regularly throughout the summer, as revealed in a leaked memo from Jane Cummings, the government's adult social care testing director. Routine testing for residents and staff was supposed to start on 6 July but, according to the memo, unexpected delays mean it will not reach all care homes until 7 September. ${ }^{1}$

Care home coronavirus testing pledge abandoned. 2 August 2020. Sunday Times. www.thetimes.co.uk/article/care-home-coronavirus-testing-pledge-abandonedtqxf6mm6j

This article is made freely available for use in accordance with BMJ's website terms and conditions for the duration of the covid-19 pandemic or until otherwise determined by BMJ. You may use, download and print the article for any lawful, non-commercial purpose (including text and data mining) provided that all copyright notices and trade marks are retained. 